\title{
Sharing the Costs: \\ The Impact of Trade Reform on Capital and Labor in Morocco
}

\author{
Janet Currie \\ University of California, Los Angeles and NBER \\ Ann Harrison \\ Columbia University and $\mathrm{NBER}^{1}$
}




\begin{abstract}
We examine the impact of recent trade reforms in Morocco. Although employment in the average private sector manufacturing firm was unaffected, there were significant employment losses in exporting firms and in the most highly affected firms. Parastatals actually increased employment, by hiring low-paid temporary workers. Many firms did not adjust either wages or employment. We examine two possible explanations. First, we explore the possibility that barriers to labor market mobility could have impeded adjustment to reform. Second, we develop a model of labor demand which allows for imperfect competition and endogenous technological change. Our results suggest that although labor markets were flexible, many firms cut profit margins and raised productivity rather than reducing employment.
\end{abstract}


$\underline{\text { Introduction }}$

There is a considerable gap in our knowledge about exactly how wages and employment in developing countries adjusted to the trade reforms of the 1970s and 1980s. On the one hand, reforms may have led to a downward shift in the demand for labor--particularly in importcompeting sectors. On the other hand, adjustment may have occurred through changes in real wages. Yet another possibility is that labor markets were unaffected and firms adjusted to greater competition through reductions in profit margins. What in fact occurred? Who paid the price?

Although the most radical trade reforms in the last two decades have occurred in developing countries, recent efforts to examine labor market adjustments to global competition have focused on industrial country experience. In part, this focus reflects lack of data: until recently, few developing country micro-level data sets covering the period coinciding with trade reforms were available.

This paper begins to fill this gap by examining the impact of a broad-based trade reform initiated in Morocco during the 1980s. As a result of pressure due to a payments crisis in 1983, Morocco virtually eliminated quantitative restrictions on imports, and reduced the maximum tariff from $165 \%$ to $45 \%$ over a six year period. These reductions are enormous compared to those typically negotiated by industrial countries. The Canada-United States Free Trade Agreement, for example, resulted in an overall reduction in Canadian tariffs of $2.5 \%$ between 1988 and 1991, and the maximum tariff reduction was under 9\% (Gaston and Trefler, 1993). Hence, the sheer magnitude of the changes in Morocco suggest that if trade reform has a significant adverse impact on wages or employment, it should be apparent in these data.

This paper contributes to the debate on trade and employment linkages in two other respects. ${ }^{1}$ First, using a new data source--micro-level detail on individual enterprises--we are able to trace the relationship between changes in trade policies and manufacturing employment at the firm level. Although trade reforms are generally implemented at the sector level, we show 
that within a sector their effects vary significantly across firm characteristics such as ownership (public versus private) and degree of export orientation. In fact, firm characteristics have a decisive impact on the response to trade reform: although the reforms in Morocco had almost no impact on aggregate wages and employment, publicly owned firms and export-oriented firms were strongly affected. By using firm-level data we are also able to directly apply a model derived from the firm's labor demand decision, and to control for unobserved, constant firm-level determinants of labor demand using firm fixed effects.

Second, our use of micro data allows us to answer a question that has puzzled labor economists in both industrial and industrializing countries. Several of the (industry level) studies that measure the impact of trade reform on wages and employment find almost no impact on wages and small effects on employment. In this paper, we analyze two possible reasons for the sluggish response. We begin by exploring the most popular explanation for the lack of an employment response: labor regulations in developing countries inhibit both the reallocation of labor and wage flexibility. Feliciano (1994) finds no impact of the Mexican trade reform on employment, attributing her results to the difficulties of firing workers under Mexican labor law. Anecdotal evidence for Venezuela suggests that employment reallocation following the trade reform in 1989 was inhibited by restrictions on layoffs in the formal sector.

We show that despite the existence of formal barriers to worker dismissals and minimum wage laws, labor market regulations cannot explain the sluggish labor market response to trade reforms in Morocco. In part, this is due to poor compliance with existing regulations. Despite the existence of a stringent minimum wage, half of all workers in the formal sector are paid below the minimum. And although firing a permanent worker in Morocco is a difficult and time consuming process, temporary workers can be easily dismissed. It is technically illegal to hire workers on repeated temporary contracts, but it appears that firms have responded to hiring and firing laws by (illegally) switching to "permanent" temporary workers.

Instead, the lack of an employment response for many of the firms in our sample can be 
explained in the context of imperfect competition. As Harrison (1994) emphasizes, many developing country markets are characterized by few players and high barriers to entry. In such a context, firms may choose to adjust to trade reform by reducing profit margins and raising productivity. These points are developed in the context of a formal model below.

We begin the paper with a discussion of necessary background information including a review of previous work on trade reform, and trade reform in Morocco. Section II discusses the model, and Section III presents the data. Section IV presents the empirical results and Section V discusses why some firms may not have adjusted wages or employment to trade reform. Section VI discusses some general equilibrium considerations. Conclusions and suggestions for future research appear in Section VII.

\section{Background}

\section{Previous Work on Trade Reform}

One of the first attempts to measure the partial equilibrium effects of import competition is Grossman (1986, 1987). Grossman analyzed the impact of tariff protection on the United States steel industry and nine other import-competing industries, finding that wages are fairly unresponsive to (tariff-inclusive) import prices but that employment responses in some sectors have been quite significant. Grossman concludes from the low wage elasticities and higher employment elasticities that there is fairly high intersectoral labor mobility within the United States. Other cross-industry studies of the United States include Freeman and Katz (1991), Revenga (1992), and Gaston and Trefler (1993). These studies also find significant effects of changes in import competition on employment, but smaller effects on wages. In the United States and Canada, it appears that trade policy changes lead to employment reallocation across industries, with very little effects on wages.

Evidence on trade and employment linkages is much weaker for developing countries. Krueger (1983) describes a project sponsored by the National Bureau of Economic Research 
(NBER) to analyze the linkages between trade policies and employment in ten industrializing countries. The NBER studies focused on (1) measuring the relative labor intensity of exportables versus import-substituting production and (2) measuring the extent to which greater protection encourages a shift towards more capital-intensive means of production. Krueger and her colleagues found that moving towards a more neutral trade regime led to greater labor intensity in production. However, none of the case studies directly measured the actual impact of trade reforms on wages or employment.

Rama (1994) adopts a partial equilibrium approach similar in spirit to Revenga (1992) and Freeman and Katz (1991) to examine the relationship between tariffs, employment, and wages in Uruguay. Using four-digit industry-level data over a six year period, Rama finds no impact of the reform on wages, but a negative impact on employment. A reduction in the tariffinclusive price of imports by $1 \%$ led to an employment drop of between .4 and .5 percentage points.

The only study that has analyzed the impact of trade reform on employment and wages using micro data is Feliciano (1994). Feliciano uses repeated cross-sections of household surveys in selected cities to examine the impact of the Mexican trade reforms on wage levels and wage dispersion. She does not find any significant impact of tariff changes on wages, but does document an increase in wage dispersion over the period of the reform. She finds no impact on aggregate industrial employment, but her sample is better suited for examining wage effects than employment effects.

\section{Trade Reform in Morocco}

Following independence in 1956, Morocco's economic development strategy was primarily based on import-substituting industrialization and agricultural self-sufficiency in a highly protected domestic market. For more than two decades, trade and industrial policies were based on high tariffs and on quantitative restrictions in imports. Furthermore, during the 1970s, 
the Moroccan government expanded growth through high levels of public spending, financed through foreign borrowing and rising receipts from phosphate exports. These policies culminated in a first balance of payments crisis in 1978, forcing authorities to implement a stabilization program with the support of the International Monetary Fund (IMF).

A second payment crisis erupted in 1983, forcing authorities to take emergency measures. All imports were subject to licensing. In consultation with the World Bank and with the support of a Trade and Industrial Policy Loan (ITPAI), the government introduced structural adjustment measures designed to eliminate the bias against export activities, liberalize the import regime, and enhance the allocative role of the financial sector (UNDP-World Bank, 1990).

The trade reform introduced in 1983 called for the eventual elimination of the Special Import Tariff (SIT), a uniform tariff levied on the c.i.f. value of imports, the lowering of the maximum customs duty from 400 to $45 \%$, and a reduction in quantitative restrictions. Changes in the industrial code were also undertaken to promote exports, and the exchange rate was devalued. Quantitative restrictions, the principal instrument of protection for domestic goods until 1984, were progressively dismantled. Most goods were gradually transferred from List B (imports requiring prior authorization for import) to List A (imports requiring no prior authorization) beginning in 1983. List C, which included all prohibited import items, was formally abolished in $1986 .^{2}$

Tables 1 and 2 document the reductions in tariff and quota coverage between 1984 and 1990. The major accomplishment of the trade reform was to substantially reduce the coverage of import licenses (quotas), from 41\% of all imports in 1984 to only 11\% of all imports in 1990. Progress in reducing tariffs was less significant, in part due to the conversion of existing quotas to tariffs. The major accomplishment of the tariff reform was to reduce the dispersion in tariff protection within the manufacturing sector. Although average tariffs declined only slightly, from $32.5 \%$ in 1984 to $28.6 \%$ in 1990 , the maximum tariff fell from $165 \%$ to $45 \%$ during the period. Average import penetration increased only slightly, in part due to domestic contraction 
combined with the devaluation.

Small changes in tariffs and import competition mask significant movements across manufacturing subsectors. The averages in Table 2 show that trade reforms in some sectors were quite dramatic. In textiles, clothing, leather products, and beverages and tobacco, significant reductions in both tariff and quota coverage led to very large increases in import penetration. These significant changes in policy allow us to use the relatively short time series available to analyze the impact of trade reform on manufacturing employment.

\section{The Model}

We assume that a firm-specific production function can be described as

(1) $q=A L^{B 1} I^{B 2}$,

where real output $q$ is a function of labor inputs $L$ and other inputs I. The input parameters B1 and B2 are assumed to be each less than unity but their sum may exceed one, indicating increasing returns to scale. The "Hicks neutral" technology parameter, A, varies over time and across plants. We assume that firms are imperfectly competitive Cournot firms. Total domestic output is given by Q, while import volumes are denoted by M. Domestic prices are denoted by $\mathrm{P}$, foreign prices are given by $\mathrm{P}^{*}$, and the exchange rate is E. Firms maximize profits subject to an industry-level quota constraint $\delta$ :

(2) $\operatorname{Max} P(Q) q-w L-r I$ subject to $M P^{*} E /\left(M P^{*} E+Q P(Q)\right) \leq \delta$.

We assume that the international price and import volumes are exogenous with respect to the individual domestic firm. The wage rate is $\mathrm{w}$ and the prices of other inputs are denoted by r. 
Domestic and imported goods are imperfect substitutes. In the spirit of Grossman $(1986,1987)$ we define the aggregate demand function as:

(3) $Q=D^{\pi t}\left\{E P^{*}(1+T A R) / P\right\}^{\epsilon}$.

where TAR are ad valorem tariffs and $\pi$ is the rate of secular demand shift.

From (2), the first order conditions with respect to $\mathrm{L}$ are given by

(3) $P \partial q / \partial L\left[1+\lambda_{1} \delta\right]=w \theta$,

where

$$
\theta \stackrel{1}{=} \underset{\left.\left.1-1 / \overline{\epsilon\left[s+\lambda_{1} \delta(1-s) /\left(1+\lambda_{1} \delta\right.\right.}\right)\right]}{ }
$$

The term $\lambda_{1}$ is the shadow value of the quota constraint. The mark-up term, $\theta$, is a positive function of an individual firm's market share s and quota coverage, but is negatively related to the elasticity of demand, $\epsilon$. Quotas also affect wages directly, with the quota premium given by the term $\left[1+\lambda_{1} \delta\right]$. Under the presence of quotas, wages are set above the value of their marginal product.

We assume that the firm's wage depends on both the alternative wage available to its employees, defined as the average wage for all other firms in the same sector, as well as its employment:

(4) $w=(A L T W A G E)^{B 3} L^{B 4}$,

where the alternative wage (ALTWAGE) is deflated by a general price index (CPI). ${ }^{3}$

The assumption that individual firms face upward sloping labor supply curves allows for the possibility of market power in the labor market (c.f. Currie, 1991). This assumption is not 
critical for either the model or the estimation of employment. However, this more general specification is useful for estimating the wage equations which are discussed later in the paper.

If we take logs, and combine (1), (2), (3), and (4), we can derive the following reduced form for employment:

$$
\text { (5) } \begin{aligned}
\log L & =\alpha_{0} t+\alpha_{1} \log I+\alpha_{2} \log A-\alpha_{3} \log A L T W A G E+\alpha_{4} \log E P^{*}+\alpha_{5} \log (1+T A R) \\
& -\alpha_{6} \log \theta+\alpha_{7} \log \left(1+\lambda_{1} \delta\right)
\end{aligned}
$$

To arrive at (5), we assume that domestic firms are symmetric, which allows us to derive a firm-specific product demand function from (3) by dividing both sides by the number of firms, $\mathrm{n}$, which is allowed to vary over time. In the estimation which follows, we will use actual quota coverage ratios (QRCOV) to measure $\delta$. QRCOV measures the share of total domestic demand that is subject to quota restrictions. To simplify the analysis, we will also assume that $\log (1+\mathrm{TAR})$ can be approximated by TAR and that the $\log (1+\mathrm{QRCOV})$ can be approximated by QRCOV.

If the elasticity of demand, $\epsilon$, is greater than one, then it is possible to sign the coefficients in (5): The model suggests that the coefficients on inputs (I), productivity (A), the foreign price level (EP*), tariffs (TAR), and quotas will all be positive; the coefficients on the alternative wage and margins $(\theta)$ are expected to be less than zero. Given that the model incorporates some market power, an elastic elasticity of demand is plausible.

We could simply estimate (5), which suggests that protection should unambiguously raise labor demand. Yet reduced form estimation of L must also take into account the fact that the level of technology (A), and the extent of market power $(\theta)$ are both in turn affected by competition from imports. Our model suggests that mark-ups should be positively related to quota coverage; for estimation, we adopt a more general specification. We hypothesize the following relationship between market power and trade policies: 
(6) $\log \theta=\eta_{0}+\eta_{1} T A R+\eta_{2} Q R C O V$, where $\eta_{1}, \eta_{2}>0$.

Later in the paper, when we estimate the relationship between margins and trade policies directly, we will be able to test the restriction that only quotas (and not tariffs) should affect mark-ups.

We would expect productivity to be affected by a number of factors. In particular, the age and type of the capital stock, and the degree of public ownership would be likely to affect productivity. We might also expect protection to exert a negative impact on productivity. We will capture such factors as age and location with a plant specific fixed effect, $\mathrm{f}_{\mathrm{i}}$. Hence:

$$
\begin{gathered}
\text { (7) } \log A=\gamma_{0}-\gamma_{1} \text { TAR }-\gamma_{2} Q R C O V+f_{i}, \\
\text { where } \gamma_{1}, \gamma_{2}>0
\end{gathered}
$$

Combining (5), (6), and (7) yields the following reduced form equation for estimation:

$$
\begin{gathered}
\text { (8) } \log L=\alpha_{0} t+\alpha_{1} \log I-\alpha_{3} \log A L T W A G E+\alpha_{4} \log E P^{*}+ \\
{\left[\alpha_{5}-\alpha_{2} \gamma_{1}-\alpha_{6} \eta_{1}\right] T A R+\left[\alpha_{7}-\alpha_{2} \gamma_{2}-\alpha_{6} \eta_{2}\right] Q R C O V+f_{i}}
\end{gathered}
$$

In a reduced form specification such as (8), employment is a positive function of other inputs and the international price $\mathrm{P}^{*}$, and a negative function of the alternative wage, ALTWAGE. However, it is not possible to sign the effects of trade policy. Changes in trade policy, as captured by tariffs (TAR) and quotas (QRCOV), have three offsetting effects on labor demand. First, increased competition from imports leads to falling output prices and a downward shift in labor demand. Second, if reducing trade barriers raises productivity, this could actually lead to an increase in labor demand. Third, lowering trade barriers reduces 
market power, which causes firms to expand production and increase labor demand. Intuitively, in an imperfectly competitive world, firms have several options when faced with greater international competition. They could cut output and reduce their labor force. Alternatively, they could respond by increasing productivity or cutting profit margins. To the extent that some rents were captured by workers in the form of higher wages, firms could also respond by cutting wages (by substituting temporary workers for permanent workers for example). In the remainder of the paper, we will attempt to disentangle these different responses by Moroccan firms to the trade reform.

\section{Public Sector Enterprises}

It is possible that public sector enterprises are significantly more constrained in their ability to fire workers than private firms. Restrictions on laying off workers can be incorporated into the model by allowing public sector firms to maximize profits subject to a constraint that $\mathrm{L}$ must be greater than or equal to some level V. If we allow for a labor constraint, it is easy to show that under the revised first order conditions, public sector firms set wages above the value of their marginal product:

(3)' $P \partial q / \partial L\left[1+\lambda_{1} \delta\right]=\left(w-\lambda_{2}\right) \theta$.

where $\lambda_{2}$ is the shadow value of the constraint. If $\mathrm{V}$ is binding, it is also easy to see that any factor which would normally lead to a reduction in labor demand, such as a decline in price or a reduction in quotas or tariffs, will have a reduced effect. In fact, public sector firms could possibly be asked to expand while other firms are contracting, acting as a social safety net for the rest of the economy. Under these circumstances, we could even see perverse (positive) effects of a reduction in tariffs or quota coverage on employment for public sector firms.

\section{Exporters}

Consider two possible types of exporters. On the one hand, there are exporters who sell 
substantially the same product in domestic and foreign markets. For these firms, output is determined by the world price, although trade restrictions may enable them to sell their product in the domestic market at a higher price. Trade reform will reduce profit margins without affecting output or employment.

On the other hand, exporters may sell substantially different products in the domestic and foreign markets. Suppose for example, that a textile manufacturer produces both a laborintensive native product and a highly mechanized product for sale on the export market. Trade reform will reduce the price of the domestic good, causing the manufacturer to shift resources from the domestic product to production of goods for the foreign market. In this case, employment will fall and productivity will rise for the exporter, and the extent of the shift will be greatest among firms that have the greatest access, experience, and expertise in foreign markets. These predictions are tested below.

\section{The Database}

The data for this paper are taken from the Moroccan Census of Manufacturing, which annually surveys all manufacturing firms with at least 10 employees or with sales revenue exceeding 100,000 dirhams (approximately US \$11,000 at the average 1984-89 official exchange rate). The number of firms in the survey averages between 4,007 (1985) and 5,200 (1989) firms a year. A survey of the informal (manufacturing) sector in 1988 suggests that the formal sector firms in the Census probably only account for 10\% of all enterprises in manufacturing, but $87 \%$ of total production and 74\% of total employment (World Bank, 1993). The firm's activity is described by a four-digit Moroccan nomenclature of economic activities (Nomenclature Marocaine des Activites Economiques or NMAE). An aggregation to two-digit codes leads to the 18 industrial sectors listed in Table 2.

The annual surveys collect firm-level information about sales revenue, output, exports, labor cost, the number of employees, and materials costs. Our model specifies that our inputs (I) 
should be included in the reduced form for labor demand. Data on capital stock is highly imperfect, and missing in about half the cases. Hence, we rely on the firm fixed effects to absorb at least the effect of mean capital stock over the period. ${ }^{4}$ However, we do include material inputs, which are calculated as the difference between (real) output and (real) value added. Plants report both the number of permanent employees and the number of days worked by temporary workers. To compute a total employment measure, the number of days worked by temporary labor was divided by 225 and added to the number of permanent employees. We estimate that the permanent (formal sector) workforce only works 225 days per year, after accounting for a five-day work week, holidays, and vacations.

The primary focus of this paper is on the employment effects of the trade reform, due to the imperfect nature of the information on wages. Moroccan firms report total expenditure on personnel ("frais de personnel"), that include both wages and social security costs. Labor costs for temporary and permanent employees are combined, making it difficult to compare the wages of the two types of workers. A firm-specific average wage was calculated by dividing the total labor bill by the total number of (permanent and temporary) employees. This wage measure reflects both changes in worker remuneration and changes in the composition of the labor force. Wages were divided by the consumer price index (CPI) to arrive at a real wage measure.

Since no measure of the international prices faced by Moroccan consumers was available, we were forced to use the US export price index series calculated by the Division of International Prices at the US Bureau of Labor Statistics. This series is compiled from interviews with individual exporters. A concordance between the US export price series, which is classified SITC revision 3, and the Moroccan classification was created. The price index was then adjusted by multiplying it by a US-Dirham exchange rate index based in the same year. Consequently, our price index takes into account both changes in international prices as well as exchange rate changes, such as the devaluation of the Moroccan currency.

Table 3 provides an overview of the firms in our data set. The original sample included 
32,280 observations, but 7,917 observations were excluded for various reasons. We excluded 1,885 observations with missing values on tariffs and quotas, as well as 3,490 observations that failed a number of cleaning checks. These included firms without employees, firms where production rose by more than $50 \%$ in one year but the labor force fell by more than $50 \%$, firms where average wages increased by more than $75 \%$, firms with average wages in excess of 500,000 dirhams, and firms where the share foreign-owned exceeded 100\%. We also excluded firms with less than 3 non-missing observations over the 7 year period, which reduced the sample size by 2,542 observations. ${ }^{5}$

The first column of Table 3 shows the mean characteristics of all firms in the sample while columns 2 through 7 illustrate the differences between various groups of firms. Panel A shows levels, while Panel B shows the difference between the mean value over the 1984 to 1986 period and the 1988 to 1990 average value.

Column 2 shows means for firms with some public ownership. Overall, only 3\% of firms have any public ownership -- the mean public share is only .01. Those firms that did have public ownership, however, tended to have a sizeable equity share controlled by the government: among firms with any public ownership, the mean share was 50\%. Although parastatals only account for a small fraction of formal sector firms, they account for a significant fraction of employment and output. In 1990, parastatals accounted for $26 \%$ of output, $11 \%$ of employment, and $30 \%$ of exports. Publicly owned firms dominate the phosphates and chemicals (including fertilizers), iron and steel, and beverages and tobacco sectors. The large role played by publicly owned firms warrants the special attention we pay to these types of plants.

A comparisons of columns 1 and 2 indicates that publicly owned firms are much larger than the average firm, and have both a higher share of temporary workers and a slightly higher share of skilled workers in the total labor force. ${ }^{6}$ (Skill levels are only available for permanent workers, and only in 1986 and 1990.) These firms also grew faster than other firms, and more of this growth was in the form of additional temporary workers. In addition, publicly held firms 
were older, had higher revenues, and paid higher wages. The positive wage differential between parastatals and other plants is remarkable, and only partly accounted for by the higher share of skilled employees.

The means comparing public firms with the rest of the manufacturing sector are striking for two reasons. First, they appear to refute the stylized "fact" that public sector employees in developing countries are underpaid (Lindauer et al, 1988), although this result must be confirmed using individual-level data from labor force surveys in which worker characteristics can be controlled for. Second, it is evident that the public sector is not unusually restricted in its ability to hire temporary workers. In fact, the share of temporary workers in publicly held firms is almost three times as high as in private firms. The high and growing share of temporary workers provides some a priori evidence against the view that parastatals are more firmly bound by labor market regulations that could impede adjustment. More evidence on the relative speeds of adjustment of publicly and privately held plants will be presented below.

The third column breaks out privately held firms in the 4 industry sectors that were most affected by trade reform, in the sense that they had the largest changes in import penetration ratios (sectors 12 through 15 in Table 1). Firms in these "high impact" sectors account for about one quarter of all private sector firms. They are larger but had somewhat lower sales and paid lower wages than other firms. However, surprisingly, both wages and employment grew faster than in the average firm. These firms also showed strong increases in both import shares and export shares, relative to the average firm, which suggests that many of these high impact firms were export-oriented and that much of the growth in employment was export led.

Trade reforms may have increased exports by reducing tariffs on imported inputs. They also coincided with an exchange rate depreciation, as described above. These factors suggest that export-oriented firms may have been net beneficiaries of the whole package of new policies. In order to investigate this hypothesis, private sector firms were broken into those with mean export shares less than .25 or greater than or equal to .25, where the means were taken over the 
whole sample period. More than four-fifths of private-sector firms had export shares smaller than .25. Export-oriented firms tend to be larger, to have more temporary workers, and to have lower wages than other firms. Panel B shows that they were also the fastest growing, although wages lagged behind those of other firms. Perhaps more surprising is the fact that despite large reductions in tariffs and quotas, the sector import share fell most for the most export-oriented firms. These figures show that if we wish to isolate the effects of tariffs and quotas, it is necessary to control for other policy changes such as exchange rate devaluations that occurred contemporaneously, and hence provide a justification for the inclusion of year effects in our empirical model.

Finally, it is worth noting one trend that affected all firms -- the share of the labor force classified as "skilled" increased over time. Although it is not shown in Table 3, we also find that the share of skilled workers in the permanent workforce rose. Coupled with the increase in the share of temporary workers, this pattern suggests that in many cases, the least skilled permanent workers were replaced with temporary workers.

\section{Results}

Table 4 shows regressions of the log of total employment on tariffs and quotas that are based on equation (8). Since this is the first study that we know of that makes use of direct measures of trade olicy, we present estimates of the impact of these two measures of trade policy separately. ${ }^{7}$ For the majority of plants, the trade reform had essentially no impact on employment. Estimates based on data aggregated up to the four-digit level are shown in the first column, for the sake of comparability with previous studies. However, for the estimation using aggregate data, we exclude the alternative wage, which is not exogenous at the industry level. These sectoral estimates suggest that trade policy had little impact on employment. The coefficients on both tariffs and quotas are statistically insignificant, with point estimates close to zero. 
Estimates based on firm level data, which include controls for firm-specific fixed effects are shown in Column 2. These figures are consistent with those obtained at the sector level, and suggest that for the average firm, trade policy measured using tariffs or quotas has no effect on employment. The point estimates on tariffs and quotas are both small in magnitude and statistically insignificant. In contrast, the coefficients are statistically significant and positive for the international price and material inputs, as well as significant negative for the alternative wage, as predicted by our model.

In columns (3) through (6), we measure the effects of trade policy on employment for different types of firms. The results suggest that firm characteristics significantly affect both the sign and the magnitude of employment responses to trade policy. Column 3 shows estimates for parastatal firms, those with some degree of public ownership. The results for employment suggest that decreases in tariffs were associated with significant increases in employment. This response is consistent with the idea that parastatal employment acts as a social safety net, absorbing employees displaced from other sectors.

Column (4) measures the impact of tariffs and quotas on firms in the most highly affected sectors. The results suggest that tariff reductions had a significant impact on employment. The coefficient on tariffs, .165, implies that a reduction in tariffs of ten percentage points would lead to a decline in employment of 1.65 percent. The impact of quotas, however, is not statistically significant.

The last two columns of Table 4 compare the responses of private sector firms with small mean export shares (an average of less than 25\% of sales over the entire period), and those with larger mean export shares. It appears that the decrease in employment due to a reduction in tariff protection is higher for export-oriented firms. In terms of our model, this result suggests that firms with export sales are likely to have lower profit margins than firms oriented primarily towards the domestic market. It appears that exporters adjusted to a contraction of the domestic market by cutting employment, while non-exporters used other means of adjustment. This 
hypothesis will be tested further below, when we explicitly examine the effects of the trade reform on profit margins.

Although the focus of our analysis is primarily on employment, we also extended the analysis to examine the relationship between wage determination and trade policy. An analogous reduced form equation for wages can be derived from combining (4) and (8). The sign of the coefficients should be the same as for labor demand, with the exception of the sign on ALTWAGE (which should now be positive). We report estimates of the wage equations in Tables $5 a$ and $5 b$.

Once again, we first report the results for the sample aggregated to the four-digit level. The coefficients on tariffs and quotas are small in magnitude and statistically insignificant. The results are unchanged in column (2), where we estimate a wage equation at the plant level for all plants in the sample. In contrast to our earlier results, however, taking into account firm characteristics generally does not alter the results in columns (1) and (2). The coefficient on tariffs and quotas is statistically insignificant except in the public sector.

Unlike private sector enterprises, parastatals show a large and significant association between tariff protection and wages. The coefficient on tariffs, .259 , suggests that a 10 percentage point decline in tariffs would lower public sector wages by 2.6 percent. In conjunction with our employment results, it appears that the public sector responded to tariff reductions by actually expanding its labor force and reducing wages. In part, the public sector responded by adding temporary workers, who are paid significantly less than permanent employees.

The results in Table 4 indicate that cross-sectoral changes in tariffs and quotas had little discernable impact on wages (with the exception of the public sector), which suggests that the labor market is fairly fluid for private firms. The results on employment also suggested that only a minority of firms actually adjusted their labor force to changes in tariffs and quotas: in particular, publicly owned firms, firms in highly affected sectors, and exporters. The lack of a 
labor market response for the majority of firms appears puzzling in light of the large tariff changes and quota reductions described earlier in the paper. In the next section, we explore alternative explanations for a sluggish response by some firms.

\section{Alternative Explanations for Different Labor Market Responses to Trade Reform}

One of the more popular explanations for the lack of a labor market response in developing countries are imperfections in the labor market. Minimum wages may impede wage adjustment, while hiring and firing laws may affect labor mobility. We discuss these possibilities below, and then turn to an alternative explanation: market power in the product market.

\section{A. Labor Market Explanations}

In Morocco, anecdotal evidence suggests that despite the existence of formal barriers to dismissals and stringent minimum wages, the labor market is actually quite fluid. In principle, private firms must first obtain permission from government bodies to fire permanent employees, and must then pay a severance payment to dismissed employees ranging from five weeks (for 5 years of service) up to 38 weeks (for 15 years of service). Yet in practice, restrictions on dismissals only apply to the largest, formal sector enterprises. In addition, many enterprises have responded to restrictions on firing permanent workers by hiring temporary employees, who can be easily dismissed. The share of temporary workers in manufacturing rose steadily between 1984 and 1990.

Another possible impediment to labor market adjustment are minimum wage laws. To the extent that minimum wages are binding, they could act as a barrier to downward wage adjustment, explaining the lack of any wage response to tariff and quota changes. In Morocco, the real value of the minimum wage rose by 4.4 percent annually during the 1980s, which suggests that it could have played an important role in the adjustment process.

In practice, however, the evidence suggests that the minimum wage did not prevent wage 
adjustment in Morocco. Harrison and Islam (1993) present evidence of widespread noncompliance with the minimum wage. Using data for 1986, they find that average wages at the plant level were below the minimum for at least half of the firms in their sample. In addition, discussions with labor inspectors suggested that they are significantly understaffed and likely to address only the most serious labor code violations. To test for the possibility that a binding minimum wage could account for sluggish wage adjustment, we re-estimated models similar to those reported here, dividing the sample into firms with average wages close to the minimum and other firms. Firms with wages close to the minimum were defined as having average wages (after subtracting out mandated payroll taxes of 12\%) within 10\% of the legislated minimum. The results were generally unaffected (and consequently are not reported here), although there is some evidence that firms with average wages close to the minimum actually experienced greater wage adjustment in response to the reforms.

One way to test whether a sluggish adjustment of the labor force could explain the low elasticities of employment response to trade form is to estimate a dynamic model of labor demand, in which employment today depends on past employment, and on determinants of current desired employment. This would allow us to examine whether a firm's response to trade shocks is related to the speed with which it adjusts to changes in desired employment levels more generally. Unfortunately, we are not able to estimate dynamic models using the whole sample of firms, because only large, well-established firms have enough observations to allow us to identify both the effect of lagged employment and the firm-specific fixed effects.

Dynamic models of labor demand are presented in Table 6. Since it is well known that the coefficient on lagged employment will be biased towards zero in the presence of fixed effects, we use a Generalized Method of Moments (GMM) procedure suggested by Arellano and Bond (1991). ${ }^{8}$ Our models include one lag of employment. We report Sargan tests of the implied over-identifying restrictions and a test of serial correlation based on the GMM residuals. ${ }^{9}$ These tests indicate that it is not necessary to include additional lags of employment. 
The results of the Sargan test show a further advantage of disaggregating the data--although the over-identifying restrictions are violated in the sample as a whole, they are not rejected when coefficients are allowed to vary with firm type.

With the exception of parastatals, all the firms have coefficients on lagged employment of 0.2 or less, indicating that employment adjustment takes place within the year. Hence, these estimates are in the same range as most of the industrial country estimates surveyed by Hammermesh (1993). ${ }^{10}$ However, it is interesting to note that in terms of speed of adjustment, private sector firms in Morocco appear to be more similar to North American firms than to European firms--the latter typically adjust employment more slowly. The coefficient on lagged employment of 0.31 for parastatals implies that they adjust much more slowly--these firms have only carried two-thirds of the eventual adjustment they will make within one year. These results suggest that the small impact of the reform cannot be attributed to an inflexible labor market, since even firms that show little adjustment to the trade reforms, appear to adjust quickly to changes in desired labor demand more generally.

\section{B. Adjusting Productivity and Profit Margins}

Our results suggest significant heterogeneity in the way firms respond to trade reform. Parastatals show perverse employment responses, while domestically oriented firms and firms outside of highly affected sectors show very little employment response at all. If our model is correct, then we expect firms with small or perverse employment responses to adjust by cutting profit margins and raising productivity.

To identify the differential impact of the trade reform on margins and productivity, we borrow the framework outlined in Harrison (1994). Returning to our earlier framework, we would like to be able to estimate the structural equations (6) and (7). We could, for example, try to derive a measure of "A", which is alternatively referred to as Hicks neutral technology or total factor productivity (TFP). Although a number of studies have in fact derived a measure of $\mathrm{A}$ in 
levels or changes and regressed it on trade policy, Harrison (1994) shows that such an approach is incorrect if there is imperfect competition. Instead, we estimate a production function that allows trade policy to affect both margins and productivity.

If we begin with the production function from equation (1), totally differentiate and divide through by q, this yields:

(9) $d q / q=(\partial q / \partial L)(d L / q)+(\partial q / \partial I)(d I / q)+d A / A$

If we combine (9) with (3) and the first order conditions for other inputs, we have the following:

(10) $d q / q=\theta[(w L / P q)(d L / L)+(r I / P q)(d I / I)]+d A / A$

The value of $\mathrm{wL} / \mathrm{Pq}$ and $\mathrm{rI} / \mathrm{Pq}$ is simply the share of each factor in total output. We will allow for one other input, materials, in the estimation. We will denote the share of labor and materials $\alpha_{1}$ and $\alpha_{\mathrm{m}}$. If we allow trade policy to affect both margins and productivity, we can estimate the following for a firm $I$ at time $t$ :

$$
\begin{aligned}
& d y_{i t}=B_{0}+B_{1} d x_{i t}+B_{2}\left[d x^{*} T A R\right]_{i t} \\
& +B_{3}\left[d x^{*} Q R C O V\right]+B_{4} T A R_{t}+B_{5} Q R C O V+d f_{i t} / f_{i t}+u_{i t} \\
& \text { where } d x=\left[\alpha_{l} d l+\alpha_{m} d m\right]_{i t}, d y_{i t}=d q / q, B_{1}=\theta \text {, } \\
& \text { and } B_{4} T A R_{t}+B_{5} Q R C O V+d f_{i t} / f_{i t}=d A / A \text {. }
\end{aligned}
$$

Lower-case variables $y, l$, and $m$ are equal to $\ln q, \ln L$, and $\ln M ; q, L$, and $M$, are firm-specific output, labor, and other inputs. The extent to which the coefficient $B_{1}$ exceeds unity is a measure of market power. The term $d f_{i t} / f_{i t}$ is a firm-specific effect in the growth rate. If productivity increased during the reform, the coefficients on tariffs and quota coverage $B_{4}$ and 
$B_{5}$ should be negative. If tariffs and quotas allow firms to exercise greater market power, then the coefficients $B_{2}$ and $B_{3}$ should be positive. Our estimation results for (11) are presented in Table 7. The coefficient on $B_{1}$ is significantly above one for all subsets of firms, indicating that Moroccan firms do exercise some market power. Margins are highest for public sector firms and lowest for exporting firms.

The positive and statistically significant coefficient for $B_{3}$ provides strong support for the hypothesis that quota protection led to greater market power, and that reductions in quota coverage also led to a reduction in margins. As suggested by the model, quotas were more likely than tariffs to have a significant impact on our measure of market power.

As expected, the trade reform was associated with significant increases in productivity, as indicated by the negative coefficients on $B_{4}$ and $B_{5}$. However, not all firms responded by raising productivity. In particular, firms in highly affected sectors failed to significantly increase productivity, in contrast to other enterprises. Surprisingly, public sector enterprises showed the greatest increases in productivity in response to reductions in quota coverage.

These results, in combination with the results presented earlier, suggest two broad approaches to the trade reform. Non-exporting, private sector firms outside of the most affected industries responded primarily by raising productivity and cutting profit margins. Firms in highly affected industries reacted primarily by cutting margins and employment, with no significant increases in productivity. Exporters reacted in every possible dimension: they cut margins, reduced employment, and raised productivity. Public sector enterprises, who increased employment in response to the reforms, nevertheless did adjust by raising productivity and lowering wages.

\section{Some General Equilibrium Considerations}

Anne Krueger's (1983) book on trade and employment in developing countries argues that trade reforms should have expansionary effects on the labor market in cases where a nation's 
comparative advantage lies in labor-intensive goods. Krueger argues that industrializing countries typically protect their capital-intensive sectors, which implies that trade reforms would increase the relative price of labor-intensive goods and expand employment in those sectors. Although this paper is primarily partial equilibrium in nature, it is interesting to speculate on whether Krueger's argument is valid for Morocco.

We begin the analysis with an examination of the firm-level data. If the trade reform did restore the comparative advantage to labor-intensive goods, then we would expect a reallocation of output towards labor-intensive firms. As a result, we would expect capital-intensive firms to make greater labor force adjustments. The first row of Table 8 confirms that this is indeed the case. If we exclude public sector firms and split the sample into two equal groups, we see that employment reallocation was only significant for firms with higher capital-labor ratios. In fact, the negative coefficients on tariffs and quotas in the first two columns of Table 8 suggest that declines in tariffs and quotas corresponded with increases in employment for labor-intensive firms, although these effects are not statistically significant. Estimates of the effects of tariffs and quotas on mark-ups and productivity (corresponding to those shown in Table 7) suggest that more capital-intensive firms reduced margins somewhat less than more labor-intensive firms but exhibited much greater increases in productivity in response to the reforms. Thus, this firm-level analysis is broadly consistent with the Krueger hypothesis.

However, most recent efforts to analyze the general equilibrium effects of trade reform on the relative returns to skilled and unskilled labor have focused not on within-industry variation but on differences across industries. The evidence in Table 9, although not conclusive, suggests that the cross-industry variation in the pattern of protection and trade reform is not consistent with the Krueger hypothesis. Although labor-intensive sectors do account for most of the labor force growth during the second half of the 1980s, these were also the most protected sectors before liberalization, and they experienced the largest declines in tariffs and quotas. Morocco is not the only developing country to protect precisely those sectors where it has the 
greatest comparative advantage: Revenga (1996) reports a similar phenomena for Mexico.

As indicated in Table 9, employment grew fastest during the second half of the 1980s in the clothing sector (sector 14), which is also the most labor-intensive sector in Morocco.

Between 1985 and 1990, the clothing sector increased its share of the manufacturing labor force from 3 percent to 22 percent. However, Table 9 also shows that clothing was one of the two most protected sectors in Morocco prior to the trade reform, and also experienced the largest declines in tariff and quota protection. How was the sector able to grow so fast and yet experience such sharp declines in tariff and quota protection ${ }^{11}$ The explanation seems to lie in the exchange rate devaluations and institutional reforms which made it increasingly attractive to produce for the export market. Together, the trends at the industry-level, and our firm-level analyses suggest that the clothing industry would have grown even faster in Morocco in the absence of trade reform, and that within this sector, it was the relatively capital-intensive firms that were most affected by reform.

\section{Conclusions and Suggestions for Future Research}

This paper examined the impact of recent trade reforms in Morocco on employment and wages. Although employment in the average firm was unaffected by the tariff reductions and the elimination of quotas, there was a significant employment response in exporting firms and in the firms most highly affected by the reforms. The 21 point decline in tariff protection experienced by firms in most affected sectors--textiles, beverages, and apparel--was associated with a 3.5\% decline in employment. Among exporting firms a 24 point decline in tariff protection was associated with nearly a 6\% decline in employment.

Our results indicate that parastatals behaved quite differently than privately held firms. They actually increased employment in response to tariff reductions, mostly by hiring low-paid temporary workers. As a result, wages fell. Productivity in these firms also increased as quota coverage fell. 
A significant fraction of manufacturing firms did not adjust either wages or employment in response to the trade reforms. We examine two possible explanations for this puzzle. First, we explore the possibility that barriers to labor market mobility, such as hiring and firing laws, could impede adjustment to reform. Our estimates of adjustment costs suggest that Morocco's formal sector labor force is in fact quite flexible, especially relative to European countries. However, as Hammermesh (1993) points out, it would be desirable to estimate dynamic models using quarterly or even monthly data because of aggregation biases. Ideally, one would also like to incorporate information about bottlenecks in other factors of production that might impede the adjustment of employment.

Second, we develop a model of labor demand which allows for imperfect competition and endogenous technological change. Our results suggests that many firms, including those that failed to adjust employment, responded to the reforms by cutting profit margins and raising productivity. This suggests another, less painful mode of adjustment: firms with excess profits could absorb the shock, leaving the labor force unaffected.

Many questions remain unanswered. Unlike industrialized countries, developing countries have big informal sectors. Before we can draw firm conclusions about the distributional impact of reform, we need to look at the effects on these workers -- perhaps using other measures of living standards besides wages (c.f. Thomas, 1994). More disaggregated wage measures--which would allow us to examine the impact of the reforms on inequality within the formal sector--would also be desirable. Finally, although we have emphasized several advantages of using firm-level panel data, there are also limitations--the most notable being that we analyze a sample of continuing firms and do not consider the effects of entry and exit. If the factors that cause existing firms to grow(shrink) also encourage entry(exit), then the total effect of the trade reforms could be larger than the effects shown above. 


\section{References}

Arellano, Manuel and Bond, Steven. "Some Tests of Specification for Panel Data: Monte Carlo

Evidence and an Application to Employment Equations", Review of Economic Studies 58 \#2

(April, 1991): 277-297.

Arellano, Manuel and Bond, Steven. "Dynamic Panel Data Estimation Using DPD--A Guide for Users", Institute for Fiscal Studies, Working Paper 88/15, London (1988).

Berman, Eli, Bound, John, and Griliches, Zvi. "Changes in the Demand for Skilled Labor within U.S. Manufacturing: Evidence form the Annual Survey of Manufactures", Quarterly Journal of Economics 109 \#2 (May 1994): 367-397.

Currie, Janet. "Employment Determination in a Unionized, Public-Sector Labor

Market: The Case of Ontario's School Teachers", $\underline{\text { Journal of Labor }}$

Economics 9 \#1 (1991): 45-66.

Davis, Steve and Haltiwanger, John. "Wage Dispersion Within and Between

U.S. Manufacturing Plants 1963-1986," Brookings Papers on Economic Activity, (1991):

$115-200$.

Deardorff,Alan V. and Hakura, D. "Trade and Wages: What are the Questions", Research Forum on International Economics Discussion Paper No. 341, University of Michigan (November 1993).

Feliciano,Zadia M., "Workers and Trade Liberalization: the Impact of Trade Reforms in Mexico on Wages and Employment", mimeo, Harvard University (1994). 
Freeman,Richard, "Labor Market Institutions and Policies: Help or Hindrance to Economic Development?", paper prepared for the world Bank's Annual Conference on Development Economics, Washington D.C. (April 1992).

Freeman, Richard and Lawrence Katz, "Industrial Wage and Employment Determination in an Open Economy", Immigration, Trade, and the Labor Market, edited by

John M. Abowd and Richard B. Freeman, Chicago: University of Chicago Press (1991).

Gaston, Noel and Trefler, Daniel. "The Role of International Trade and Trade Policy in the Labour Markets of Canada and the United States", 47 \#4 World Economy (January, 1994): 4562.

Grossman, Gene, "Imports as a Cause of Injury: The Case of the US. Steel Industry", $\underline{\text { Journal of }}$ International Economics 20 (1986): 201-23.

Grossman, Gene, "The Employment and Wage Effects on Import Competition in the United States", Journal of International Economic Integration 2 (1987): 1-23.

Hammermesh, Daniel. Labor Demand, Princeton University Press:

Princeton NJ (1993).

Harrison, Ann E. and Islam, Roumeen. "Morocco Private Sector Assessment: the Labor Market", mimeo, World Bank (1993).

Harrison, Ann E., "Productivity, Imperfect Competition and Trade Reform: Theory and 
Evidence, Journal of International Economics 36 \#1-2 (February, 1994): 53-73.

Krueger, Anne O., Trade and Employment in Developing Countries, Chicago: University of Chicago Press (1983).

Lindauer, David, Meesok, O.A. and Suebsaeng, P. "Government Wage Policy in Africa: Some Findings and Policy Issues", World Bank Research Observer (January, 1988).

Rama, Martin, "The Labor Market and trade reform in Manufacturing", in The Effects of Protectionism on a Small Country, edited by Michael Connolly and Jaime de Melo, Washington D.C.: World Bank Regional and Sectoral Studies (1994).

Revenga, Anna, "Exporting Jobs? The Impact of Import Competition on Employment and Wages in U.S. Manufacturing", Quarterly Journal of Economics" 107 \#1 (February 1992): 255284.

Thomas, Duncan. "Public Policy and Anthropometric Outcomes in Cote d'Ivoire", 61 \#2 Journal of Public Economics 61 \#2 (August, 1996): 155-192.

UNDP-World Bank Trade Expansion Program, Morocco 2000: An Open and Competitive Economy, Washington D.C.: The World Bank, Country Report 7 (November 1990).

World Bank,"The Kingdom of Morocco: Developing Private Industry in Morocco", Washington D.C.: The World Bank, Report No. 11557-MOR (January 1993). 
Table 1: Trade Reform in Morocco, 1984-1990

\begin{tabular}{|c|c|c|c|c|c|c|c|}
\hline & 1984 & 1985 & 1986 & 1987 & 1988 & 1989 & 1990 \\
\hline $\begin{array}{l}\text { Average Tariff } \\
\left(\frac{\circ}{0}\right)\end{array}$ & 32.5 & 32.7 & 32.5 & 30.2 & 28.0 & 28.5 & 28.6 \\
\hline $\begin{array}{l}\text { Maximum Tariff } \\
\left(\frac{\circ}{0}\right)\end{array}$ & 158.2 & 165.0 & 165.6 & 106.1 & 45.0 & 45.0 & 45.0 \\
\hline $\begin{array}{l}\text { Coverage of } \\
\text { Import } \\
\text { Licenses }(\%)\end{array}$ & 41.0 & 36.1 & 29.3 & 25.7 & 23.0 & 17.0 & 11.3 \\
\hline $\begin{array}{l}\text { Import } \\
\text { Penetration } \\
\left(\frac{\circ}{0}\right)^{\frac{1}{1}}\end{array}$ & $\begin{array}{c}37.6 \\
(36.3)\end{array}$ & $\begin{array}{c}37.4 \\
(35.0)\end{array}$ & $\begin{array}{c}36.4 \\
(34.0)\end{array}$ & $\begin{array}{c}36.7 \\
(33.8)\end{array}$ & $\begin{array}{c}36.5 \\
(33.5)\end{array}$ & $\begin{array}{l}38.6 \\
(34.8)\end{array}$ & $\begin{array}{l}39.0 \\
(35.1)\end{array}$ \\
\hline
\end{tabular}

1/ Import penetration defined as Imports/(Imports + Sales - Exports). Number in parentheses gives alternative definition of import penetration as Imports/(Imports + Sales). 
Table 2: Trade Reform by Manufacturing Subsector

\begin{tabular}{|c|c|c|c|c|c|c|c|c|c|}
\hline \multirow[b]{3}{*}{10} & \multirow[b]{3}{*}{ Food Products } & \multicolumn{2}{|c|}{ Tariffs } & \multicolumn{2}{|c|}{$\begin{array}{l}\text { Quota } \\
\text { Coverage }\end{array}$} & \multicolumn{4}{|c|}{ Import Penetration ${ }^{1 /}$} \\
\hline & & \multirow{2}{*}{$\begin{array}{c}1984 \\
23.0\end{array}$} & \multirow{2}{*}{$\begin{array}{c}1990 \\
32.8\end{array}$} & \multirow{2}{*}{$\begin{array}{c}1984 \\
35.9\end{array}$} & \multirow{2}{*}{$\begin{array}{l}\mathbf{1 9 9 0} \\
24.6\end{array}$} & \multicolumn{2}{|c|}{1984} & \multicolumn{2}{|c|}{1990} \\
\hline & & & & & & 5.0 & $(5.0)$ & 6.3 & $(6.2)$ \\
\hline 11 & Other Food Products & 49.7 & 32.3 & 68.0 & 33.9 & 36.4 & (35.7) & 30.5 & $(27.3)$ \\
\hline 12 & Beverages and Tobacco & 90.6 & 36.6 & 73.3 & 20.1 & 3.5 & $(3.5)$ & 21.8 & $(21.8)$ \\
\hline 13 & Textiles & 52.9 & 35.6 & 75.6 & 55.7 & 27.0 & $(25.7)$ & 37.1 & (30.7) \\
\hline 14 & Clothing & 70.5 & 44.7 & 93.3 & 26.0 & 3.6 & $(2.3)$ & 10.1 & $(3.5)$ \\
\hline 15 & Leather and Shoes & 43.0 & 31.7 & 69.7 & 32.8 & 22.6 & $(20.3)$ & 39.3 & $(21.9)$ \\
\hline 16 & Wood Products & 26.6 & 25.8 & 54.4 & 0 & 20.2 & $(19.1)$ & 20.8 & $(18.6)$ \\
\hline 17 & Paper and Printing & 17.4 & 25.6 & 70.1 & 0 & 24.4 & $(24.4)$ & 20.6 & (18.9) \\
\hline 18 & Mineral Products & 23.9 & 29.1 & 28.3 & 0 & 11.3 & (11.0) & 13.9 & (13.5) \\
\hline 19 & Basic Metals & 9.3 & 13.1 & 17.4 & 0 & 68.7 & (59.4) & 68.3 & $(55.8)$ \\
\hline 20 & Metallic Products & 31.7 & 32.6 & 37.2 & 0 & 22.5 & $(22.3)$ & 25.8 & $(25.2)$ \\
\hline 21 & $\begin{array}{l}\text { Machinery and } \\
\text { Equipment }\end{array}$ & 11.5 & 16.3 & 22.0 & 2.8 & 73.6 & (73.5) & 69.8 & (69.7) \\
\hline 22 & Transport Materials & 15.9 & 22.8 & 27.8 & 4.6 & 66.5 & (65.2) & 62.0 & (57.6) \\
\hline 22 & & 21.6 & 27.5 & 18.7 & 1.0 & 56.7 & $(53.0)$ & 57.0 & (46.3) \\
\hline 23 & Precision Equipment & 22.9 & 26.3 & 6.7 & 0 & 85.6 & $(81.0)$ & 81.8 & (81.3) \\
\hline 24 & Chemical Products & 21.3 & 20.8 & 22.6 & 6.5 & 31.2 & (30.5) & 35.2 & (29.3) \\
\hline 25 & Rubber and Plastics & 33.0 & 36.3 & 48.8 & 2.1 & 29.1 & $(29.0)$ & 35.2 & (33.9) \\
\hline 26 & Other Industrial Product & 55.3 & 39.0 & 27.6 & 0 & 80.9 & (80.5) & 78.3 & (75.6) \\
\hline
\end{tabular}

1/ See footnote 1 in Table 1. 
Table 3: Variable Means

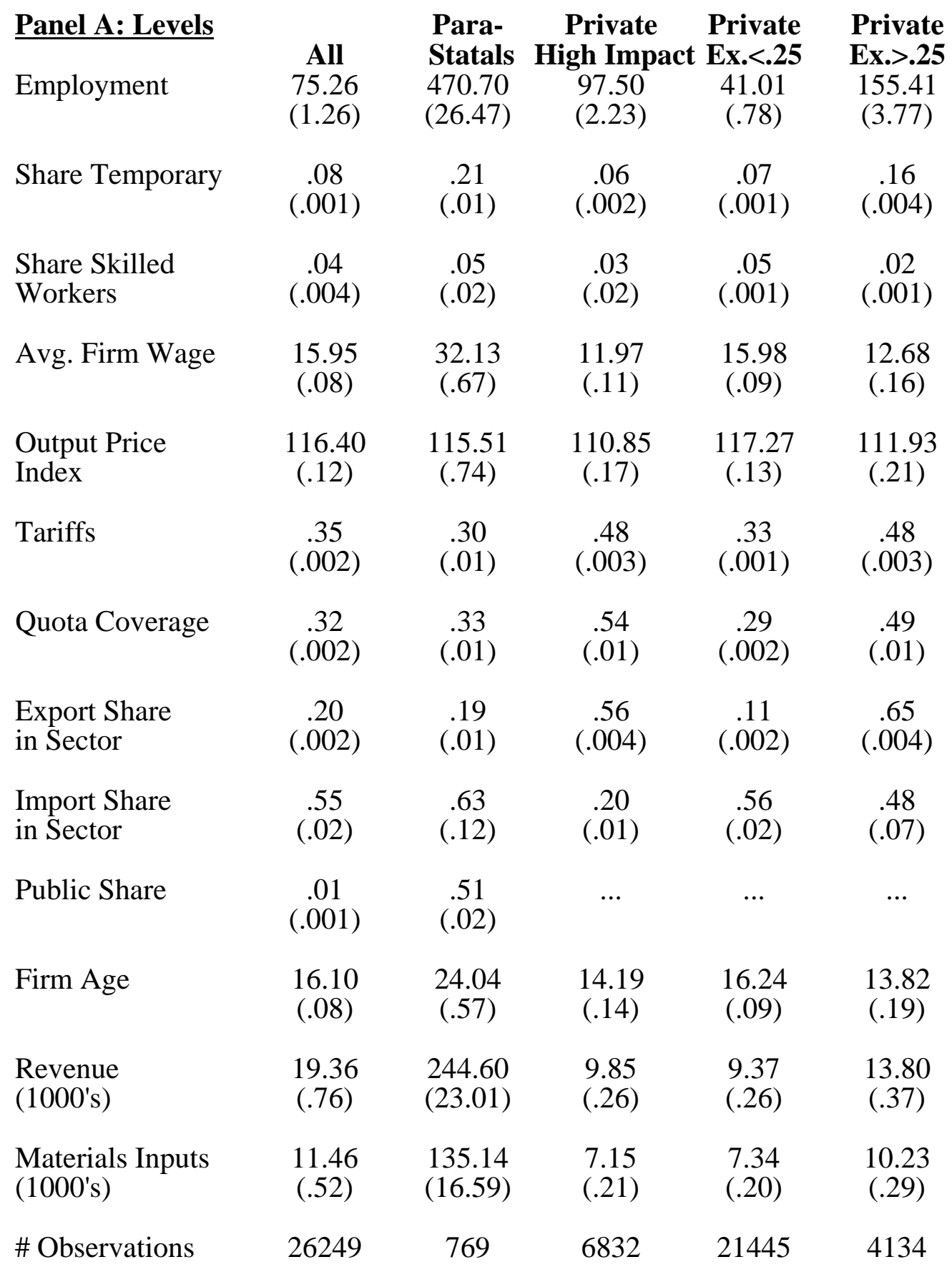


Panel B: Difference 88-90 Average and 84-86 Average

\begin{tabular}{|c|c|c|c|c|c|}
\hline Total Employment & $\begin{array}{c}\text { All } \\
14.36 \\
(1.85)\end{array}$ & $\begin{array}{l}\text { Para- } \\
\text { Statals } \\
78.74 \\
(31.29)\end{array}$ & $\begin{array}{c}\text { Private } \\
\text { High Impact } \\
20.98 \\
(1.40)\end{array}$ & $\begin{array}{c}\text { Private } \\
\text { Ex.<.25 } \\
5.54 \\
(.44)\end{array}$ & $\begin{array}{c}\text { Private } \\
\text { Ex.>.25 } \\
52.74 \\
(3.40)\end{array}$ \\
\hline Share Temporary & $\begin{array}{c}.03 \\
(.002)\end{array}$ & $\begin{array}{c}.07 \\
(.07)\end{array}$ & $\begin{array}{c}.02 \\
(.002)\end{array}$ & $\begin{array}{c}.02 \\
(.001)\end{array}$ & $\begin{array}{c}.04 \\
(.003)\end{array}$ \\
\hline $\begin{array}{l}\text { Share Skilled } \\
\text { Workers }\end{array}$ & $\begin{array}{c}.16 \\
(.003)\end{array}$ & $\begin{array}{c}.04 \\
(.01)\end{array}$ & $\begin{array}{c}.02 \\
(.001)\end{array}$ & $\begin{array}{c}.03 \\
(.001)\end{array}$ & $\begin{array}{c}.01 \\
(.001)\end{array}$ \\
\hline Avg. Firm Wage & $\begin{array}{l}1.42 \\
(.13)\end{array}$ & $\begin{array}{c}1.66 \\
(1.03)\end{array}$ & $\begin{array}{l}1.65 \\
(.06)\end{array}$ & $\begin{array}{l}1.50 \\
(.05)\end{array}$ & $\begin{array}{l}1.24 \\
(.19)\end{array}$ \\
\hline $\begin{array}{l}\text { Output Price } \\
\text { Index }\end{array}$ & $\begin{array}{l}27.68 \\
(.23)\end{array}$ & $\begin{array}{l}29.95 \\
(1.60)\end{array}$ & $\begin{array}{c}23.46 \\
(.11)\end{array}$ & $\begin{array}{c}29.02 \\
(.10)\end{array}$ & $\begin{array}{c}.96 \\
(.03)\end{array}$ \\
\hline Tariffs & $\begin{array}{c}-.04 \\
(.003)\end{array}$ & $\begin{array}{l}-.07 \\
(.02)\end{array}$ & $\begin{array}{c}-.20 \\
(.005)\end{array}$ & $\begin{array}{c}-.02 \\
(.001)\end{array}$ & $\begin{array}{c}-.22 \\
(.005)\end{array}$ \\
\hline Quota Coverage & $\begin{array}{c}-.17 \\
(.004)\end{array}$ & $\begin{array}{l}-.16 \\
(.02)\end{array}$ & $\begin{array}{c}-.26 \\
(.005)\end{array}$ & $\begin{array}{c}-.02 \\
(.001)\end{array}$ & $\begin{array}{l}-.27 \\
(.01)\end{array}$ \\
\hline $\begin{array}{l}\text { Export Share } \\
\text { in Sector }\end{array}$ & $\begin{array}{c}.04 \\
(.002)\end{array}$ & $\begin{array}{c}.04 \\
(.01)\end{array}$ & $\begin{array}{c}.12 \\
(.002)\end{array}$ & $\begin{array}{c}.03 \\
(.001)\end{array}$ & $\begin{array}{c}.12 \\
(.002)\end{array}$ \\
\hline $\begin{array}{l}\text { Import Share } \\
\text { in Sector }\end{array}$ & $\begin{array}{l}-.15 \\
(.05)\end{array}$ & $\begin{array}{c}.01 \\
(.05)\end{array}$ & $\begin{array}{c}.07 \\
(.01)\end{array}$ & $\begin{array}{l}-.13 \\
(.02)\end{array}$ & $\begin{array}{l}-.29 \\
(.14)\end{array}$ \\
\hline Public Share & $\begin{array}{l}.001 \\
(.03)\end{array}$ & $\begin{array}{c}.02 \\
(.001)\end{array}$ & $\ldots$ & ... & $\cdots$ \\
\hline $\begin{array}{l}\text { Revenue } \\
\text { (1000s) }\end{array}$ & $\begin{array}{l}7.65 \\
(.87)\end{array}$ & $\begin{array}{c}95.59 \\
(25.76)\end{array}$ & $\begin{array}{l}1.55 \\
(.12)\end{array}$ & $\begin{array}{l}1.19 \\
(.88)\end{array}$ & $\begin{array}{l}3.56 \\
(.23)\end{array}$ \\
\hline
\end{tabular}

Notes: "High Impact" refers to firms most affected by the changes in tariffs and quotas. Standard errors in parentheses. 
Table 4a: Effects of Trade on Employment: Tariffs

\begin{tabular}{||l|c|c|c|c|c|c||}
\hline \hline & $\begin{array}{c}\text { All- } \\
\text { Industry } \\
\text { Level }\end{array}$ & $\begin{array}{c}\text { All-Firm } \\
\text { Level }\end{array}$ & $\begin{array}{c}\text { Para- } \\
\text { Statals }\end{array}$ & $\begin{array}{c}\text { Private } \\
\text { High } \\
\text { Impact }\end{array}$ & $\begin{array}{c}\text { Private } \\
\text { Exports } \\
<25 \%\end{array}$ & $\begin{array}{c}\text { Private } \\
\text { Exports } \\
>25 \%\end{array}$ \\
\hline Tariff & $\begin{array}{c}0.002 \\
(.143)\end{array}$ & $\begin{array}{c}0.002 \\
(.03)\end{array}$ & $\begin{array}{c}-0.255 \\
(.121)\end{array}$ & $\begin{array}{c}.165 \\
(.055)\end{array}$ & $\begin{array}{c}.069 \\
(.037)\end{array}$ & $\begin{array}{c}.233 \\
(.081)\end{array}$ \\
\hline $\begin{array}{l}\text { International } \\
\text { Price }\end{array}$ & $\begin{array}{c}.119 \\
(.432)\end{array}$ & $\begin{array}{c}0.223 \\
(0.051)\end{array}$ & $\begin{array}{c}.031 \\
(.242)\end{array}$ & $\begin{array}{c}.010 \\
(.127)\end{array}$ & $\begin{array}{c}.235 \\
(.056)\end{array}$ & $\begin{array}{c}-0.065 \\
(.152)\end{array}$ \\
\hline $\begin{array}{l}\text { Log Alternative } \\
\text { Wage }\end{array}$ & -- & $\begin{array}{c}-0.066 \\
(.019)\end{array}$ & $\begin{array}{c}-0.055 \\
(.103)\end{array}$ & $\begin{array}{c}-0.031 \\
(.048)\end{array}$ & $\begin{array}{c}-0.040 \\
(.020)\end{array}$ & $\begin{array}{c}-0.164 \\
(.060)\end{array}$ \\
\hline Log Materials & .759 & $\begin{array}{c}0.133 \\
(.004)\end{array}$ & $\begin{array}{c}.097 \\
(.028)\end{array}$ & $\begin{array}{c}.174 \\
(.009)\end{array}$ & $\begin{array}{c}.122 \\
(.004)\end{array}$ & $\begin{array}{c}0.198 \\
(.013)\end{array}$ \\
\hline R-Square & & $.911)$ & .96 & .95 & .95 & .92 \\
\hline
\end{tabular}

Table 4b: Effects of Trade on Employment: Quotas

\begin{tabular}{||l|c|c|c|c|c|c||}
\hline \hline & $\begin{array}{c}\text { All- } \\
\text { Industry } \\
\text { Level }\end{array}$ & $\begin{array}{c}\text { All-Firm } \\
\text { Level }\end{array}$ & $\begin{array}{c}\text { Para- } \\
\text { Statals }\end{array}$ & $\begin{array}{c}\text { Private } \\
\text { High } \\
\text { Impact }\end{array}$ & $\begin{array}{c}\text { Private } \\
\text { Exports } \\
<25 \%\end{array}$ & $\begin{array}{c}\text { Private } \\
\text { Exports } \\
>25 \%\end{array}$ \\
\hline Quota Coverage & $\begin{array}{c}0.057 \\
(.088)\end{array}$ & $\begin{array}{c}0.010 \\
(.017)\end{array}$ & $\begin{array}{c}-0.003 \\
(.098)\end{array}$ & $\begin{array}{c}-0.048 \\
(.034)\end{array}$ & $\begin{array}{c}.044 \\
(.019)\end{array}$ & $\begin{array}{c}-0.049 \\
(.048)\end{array}$ \\
\hline $\begin{array}{l}\text { International } \\
\text { Price }\end{array}$ & $\begin{array}{c}0.057 \\
(.431)\end{array}$ & $\begin{array}{c}0.220 \\
(0.051)\end{array}$ & $\begin{array}{c}.083 \\
(.243)\end{array}$ & $\begin{array}{c}.003 \\
(.128)\end{array}$ & $\begin{array}{c}.237 \\
(.056)\end{array}$ & $\begin{array}{c}-0.057 \\
(.158)\end{array}$ \\
\hline $\begin{array}{l}\text { Log Alternative } \\
\text { Wage }\end{array}$ & -- & $\begin{array}{c}-0.066 \\
(.019)\end{array}$ & $\begin{array}{c}-.084 \\
(.104)\end{array}$ & $\begin{array}{c}0.008 \\
(.046)\end{array}$ & $\begin{array}{c}-0.042 \\
(.020)\end{array}$ & $\begin{array}{c}-0.137 \\
(.060)\end{array}$ \\
\hline Log Materials & 0.759 & $\begin{array}{c}0.133 \\
(.004)\end{array}$ & $\begin{array}{c}0.088 \\
(.028)\end{array}$ & $\begin{array}{c}.173 \\
(.009)\end{array}$ & $\begin{array}{c}0.122 \\
(.004)\end{array}$ & $\begin{array}{c}0.120 \\
(.013)\end{array}$ \\
\hline R-Square & .85 & .96 & .96 & .95 & .95 & .92 \\
\hline No. of Obs. & 1172 & 21098 & 612 & 4834 & 17363 & 3123 \\
\hline No. of Firms & -- & 4475 & 116 & 1118 & 3622 & 735 \\
\hline
\end{tabular}

Notes: Standard errors in parentheses. All equations include time dummies. 
Table 5a: Effects of Trade on Wages: Tariffs

\begin{tabular}{||l|c|c|c|c|c|c||}
\hline \hline & $\begin{array}{c}\text { All- } \\
\text { Industry } \\
\text { Level }\end{array}$ & $\begin{array}{c}\text { All-Firm } \\
\text { Level }\end{array}$ & $\begin{array}{c}\text { Para- } \\
\text { Statals }\end{array}$ & $\begin{array}{c}\text { Private } \\
\text { High } \\
\text { Impact }\end{array}$ & $\begin{array}{c}\text { Private } \\
\text { Exports } \\
<25 \%\end{array}$ & $\begin{array}{c}\text { Private } \\
\text { Exports } \\
>25 \%\end{array}$ \\
\hline Tariff & $\begin{array}{c}-0.003 \\
(.001)\end{array}$ & $\begin{array}{c}0.033 \\
(.019)\end{array}$ & $\begin{array}{c}0.259 \\
(.100)\end{array}$ & $\begin{array}{c}-.035 \\
(.053)\end{array}$ & $\begin{array}{c}-.049 \\
(.038)\end{array}$ & $\begin{array}{c}-.118 \\
(.077)\end{array}$ \\
\hline $\begin{array}{l}\text { International } \\
\text { Price }\end{array}$ & $\begin{array}{c}0.004 \\
(.290)\end{array}$ & $\begin{array}{c}-0.011 \\
(0.051)\end{array}$ & $\begin{array}{c}.003 \\
(.200)\end{array}$ & $\begin{array}{c}.109 \\
(.123)\end{array}$ & $\begin{array}{c}.002 \\
(.057)\end{array}$ & $\begin{array}{c}-0.013 \\
(.144)\end{array}$ \\
\hline Log Alternative & -- & $\begin{array}{c}0.033 \\
\text { Wage }\end{array}$ & $\begin{array}{c}0.237 \\
(.019)\end{array}$ & $\begin{array}{c}0.006 \\
(.047)\end{array}$ & $\begin{array}{c}0.002 \\
(.021)\end{array}$ & $\begin{array}{c}0.155 \\
(.057)\end{array}$ \\
\hline Log Materials & $\begin{array}{c}0.098 \\
(.007)\end{array}$ & $\begin{array}{c}0.044 \\
(.004)\end{array}$ & $\begin{array}{c}.021 \\
(.023)\end{array}$ & $\begin{array}{c}.042 \\
(.008)\end{array}$ & $\begin{array}{c}.043 \\
(.004)\end{array}$ & $\begin{array}{c}0.052 \\
(.0112)\end{array}$ \\
\hline R-Square & .35 & .83 & .86 & .79 & .83 & .75 \\
\hline
\end{tabular}

Table 5b: Effects of Trade on Wages: Quotas

\begin{tabular}{||l|c|c|c|c|c|c||}
\hline \hline & $\begin{array}{c}\text { All- } \\
\text { Industry } \\
\text { Level }\end{array}$ & $\begin{array}{c}\text { All-Firm } \\
\text { Level }\end{array}$ & $\begin{array}{c}\text { Para- } \\
\text { Statals }\end{array}$ & $\begin{array}{c}\text { Private } \\
\text { High } \\
\text { Impact }\end{array}$ & $\begin{array}{c}\text { Private } \\
\text { Exports } \\
<25 \%\end{array}$ & $\begin{array}{c}\text { Private } \\
\text { Exports } \\
>25 \%\end{array}$ \\
\hline Quota Coverage & $\begin{array}{c}0.012 \\
(.059)\end{array}$ & $\begin{array}{c}0.019 \\
(.017)\end{array}$ & $\begin{array}{c}0.006 \\
(.081)\end{array}$ & $\begin{array}{c}-0.006 \\
(.033)\end{array}$ & $\begin{array}{c}.002 \\
(.019)\end{array}$ & $\begin{array}{c}0.068 \\
(.045)\end{array}$ \\
\hline $\begin{array}{l}\text { International } \\
\text { Price }\end{array}$ & $\begin{array}{c}.093 \\
(.292)\end{array}$ & $\begin{array}{c}-0.016 \\
(0.051)\end{array}$ & $\begin{array}{c}-.051 \\
(.202)\end{array}$ & $\begin{array}{c}.118 \\
(.123)\end{array}$ & $\begin{array}{c}-.005 \\
(.057)\end{array}$ & $\begin{array}{c}-0.056 \\
(.149)\end{array}$ \\
\hline Log Alternative & -- & $\begin{array}{c}0.032 \\
\text { Wage }\end{array}$ & $\begin{array}{c}.264 \\
(.019)\end{array}$ & $\begin{array}{c}-0.002 \\
(.045)\end{array}$ & $\begin{array}{c}0.003 \\
(.021)\end{array}$ & $\begin{array}{c}0.139 \\
(.057)\end{array}$ \\
\hline Log Materials & .099 & $\begin{array}{c}0.044 \\
(.004)\end{array}$ & $\begin{array}{c}0.031 \\
(.023)\end{array}$ & $\begin{array}{c}.042 \\
(.008)\end{array}$ & $\begin{array}{c}0.043 \\
(.004)\end{array}$ & $\begin{array}{c}0.051 \\
(.012)\end{array}$ \\
\hline R-Square & .34 & .83 & .86 & .79 & .83 & .75 \\
\hline No. of Obs. & 1172 & 21098 & 612 & 4834 & 17363 & 3123 \\
\hline No. of Firms & -- & 4475 & 116 & 1118 & 3622 & 735 \\
\hline
\end{tabular}

Notes: Standard errors in parentheses. All equations include time dummies. 
Table 6: GMM Estimates (All Variables in First Differences) of Log Employment with Adjustment Costs

Table 6a: Measuring Trade Policy with Tariffs

\begin{tabular}{||l|c|c|c|c|c||}
\hline \hline & $\begin{array}{c}\text { All-Firm } \\
\text { Level }\end{array}$ & $\begin{array}{c}\text { Para- } \\
\text { Statals }\end{array}$ & $\begin{array}{c}\text { Private } \\
\text { High } \\
\text { Impact }\end{array}$ & $\begin{array}{c}\text { Private } \\
\text { Exports } \\
<25 \%\end{array}$ & $\begin{array}{c}\text { Private } \\
\text { Exports } \\
>25 \%\end{array}$ \\
\hline $\begin{array}{l}\text { Lag(ln } \\
\text { employment) }\end{array}$ & $\begin{array}{c}.157 \\
(.045)\end{array}$ & $\begin{array}{c}.310 \\
(.084)\end{array}$ & $\begin{array}{c}.074 \\
(.118)\end{array}$ & $\begin{array}{c}.197 \\
(.043)\end{array}$ & $\begin{array}{c}.070 \\
(.132)\end{array}$ \\
\hline Tariff & $\begin{array}{c}-0.057 \\
(.060)\end{array}$ & $\begin{array}{c}-0.222 \\
(.135)\end{array}$ & $\begin{array}{c}.087 \\
(.096)\end{array}$ & $\begin{array}{c}.041 \\
(.069)\end{array}$ & $\begin{array}{c}.053 \\
(.169)\end{array}$ \\
\hline $\begin{array}{l}\text { International } \\
\text { Price }\end{array}$ & $\begin{array}{c}0.039 \\
(0.086)\end{array}$ & $\begin{array}{c}.167 \\
(.254)\end{array}$ & $\begin{array}{c}-.068 \\
(.195)\end{array}$ & $\begin{array}{c}.014 \\
(.092)\end{array}$ & $\begin{array}{c}-0.084 \\
(.249)\end{array}$ \\
\hline $\begin{array}{l}\text { Log Alternative } \\
\text { Wage }\end{array}$ & $\begin{array}{c}0.009 \\
(.033)\end{array}$ & $\begin{array}{c}-0.099 \\
(.112)\end{array}$ & $\begin{array}{c}0.077 \\
(.072)\end{array}$ & $\begin{array}{c}0.027 \\
(.036)\end{array}$ & $\begin{array}{c}-0.054 \\
(.108)\end{array}$ \\
\hline Log Materials & $\begin{array}{c}0.067 \\
(.009)\end{array}$ & $\begin{array}{c}.064 \\
(.019)\end{array}$ & $\begin{array}{c}.084 \\
(.021)\end{array}$ & $\begin{array}{c}.061 \\
(.009)\end{array}$ & $\begin{array}{c}0.127 \\
(.027)\end{array}$ \\
\hline Sargan Test & 31.1 & 8.0 & 11.3 & 18.7 & 10.7 \\
\hline A-B Test & -.84 & -.91 & .91 & -.09 & -.69 \\
\hline \hline
\end{tabular}


Table 6b: Measuring Trade Policy with Quotas

\begin{tabular}{||l|c|c|c|c|c||}
\hline & $\begin{array}{c}\text { All-Firm } \\
\text { Level }\end{array}$ & $\begin{array}{c}\text { Para- } \\
\text { Statals }\end{array}$ & $\begin{array}{c}\text { Private } \\
\text { High } \\
\text { Impact }\end{array}$ & $\begin{array}{c}\text { Private } \\
\text { Exports } \\
<25 \%\end{array}$ & $\begin{array}{c}\text { Private } \\
\text { Exports } \\
>25 \%\end{array}$ \\
\hline $\begin{array}{l}\text { Lag(ln } \\
\text { employment) }\end{array}$ & $\begin{array}{c}.159 \\
(.045)\end{array}$ & $\begin{array}{c}.303 \\
(.085)\end{array}$ & $\begin{array}{c}0.074 \\
(.012)\end{array}$ & $\begin{array}{c}.200 \\
(.043)\end{array}$ & $\begin{array}{c}.068 \\
(.132)\end{array}$ \\
\hline Quota Coverage & $\begin{array}{c}-0.054 \\
(.032)\end{array}$ & $\begin{array}{c}0.085 \\
(.087)\end{array}$ & $\begin{array}{c}-.175 \\
(. .076)\end{array}$ & $\begin{array}{c}-.033 \\
(.035)\end{array}$ & $\begin{array}{c}-.098 \\
(.100)\end{array}$ \\
\hline International \\
Price & $\begin{array}{c}0.036 \\
(0.086)\end{array}$ & $\begin{array}{c}.160 \\
(.263)\end{array}$ & $\begin{array}{c}-0.038 \\
(.196)\end{array}$ & $\begin{array}{c}.009 \\
(.092)\end{array}$ & $\begin{array}{c}-0.021 \\
(.255)\end{array}$ \\
\hline Log Alternative & $\begin{array}{c}0.004 \\
\text { Wage }\end{array}$ & $\begin{array}{c}-0.104 \\
(.033)\end{array}$ & $\begin{array}{c}0.082 \\
(.071)\end{array}$ & $\begin{array}{c}0.025 \\
(.036)\end{array}$ & $\begin{array}{c}-0.061 \\
(.106)\end{array}$ \\
\hline Log Materials & $\begin{array}{c}0.067 \\
(.009)\end{array}$ & $\begin{array}{c}.064 \\
(.019)\end{array}$ & $\begin{array}{c}.084 \\
(.021)\end{array}$ & $\begin{array}{c}.061 \\
(.009)\end{array}$ & $\begin{array}{c}0.126 \\
(.027)\end{array}$ \\
\hline Sargan Test & 31.9 & 8.8 & 12.2 & 18.5 & 10.7 \\
\hline A-B Test & -.82 & -.92 & 0.96 & -0.07 & -0.75 \\
\hline Number of Obs. & 7668 & 296 & 1348 & 6612 & 760 \\
\hline Nmber of Firms & 1917 & 74 & 337 & 1253 & 190 \\
\hline \hline
\end{tabular}

\section{Notes:}

Standard errors in parentheses. All regressions include 5 time dummies. The Sargan test is an overidentification test distributed as a chi-square with 14 degrees of freedom. The critical value is 23.68 at the $95 \%$ confidence level. The A-B test is a test of second order serial correlation, which is distributed as a standard normal. It is described in more detail in Arellano and Bond (1991). 
Table 7a: Impact of Tariffs on Margins and Productivity

\begin{tabular}{||l|c|c|c|c|c||}
\hline \hline & $\begin{array}{c}\text { All } \\
\text { Firm- } \\
\text { Level }\end{array}$ & $\begin{array}{c}\text { Para- } \\
\text { Statals }\end{array}$ & $\begin{array}{c}\text { Private } \\
\text { High } \\
\text { Impact }\end{array}$ & $\begin{array}{c}\text { Private } \\
\text { Exports } \\
<25 \%\end{array}$ & $\begin{array}{c}\text { Private } \\
\text { Exports }> \\
25 \%\end{array}$ \\
\hline$B_{1}$ (Measure of Mark-ups) & $\begin{array}{c}1.097 \\
(.004)\end{array}$ & $\begin{array}{c}1.159 \\
(.023)\end{array}$ & $\begin{array}{c}1.071 \\
(.009)\end{array}$ & $\begin{array}{c}1.090 \\
(.005)\end{array}$ & $\begin{array}{c}1.049 \\
(0.013)\end{array}$ \\
\hline $\begin{array}{l}B_{2} \text { (Impact of Tariffs on } \\
\text { Market Power) }\end{array}$ & $\begin{array}{c}0.000 \\
(0.009)\end{array}$ & $\begin{array}{c}0.078 \\
(.071)\end{array}$ & $\begin{array}{c}0.040 \\
(.016)\end{array}$ & $\begin{array}{c}0.012 \\
(0.012)\end{array}$ & $\begin{array}{c}0.053 \\
(.021)\end{array}$ \\
\hline $\begin{array}{c}B_{4} \text { (Impact of Tariffs on } \\
\text { Productivity) }\end{array}$ & $\begin{array}{c}-0.044 \\
(.022)\end{array}$ & $\begin{array}{c}-0.002 \\
(.146)\end{array}$ & $\begin{array}{c}-0.039 \\
(.034)\end{array}$ & $\begin{array}{c}-0.040 \\
(0.027)\end{array}$ & $\begin{array}{c}-0.146 \\
(0.047)\end{array}$ \\
\hline R-Square & .96 & .96 & .97 & .97 & .96 \\
\hline Number of Observations & 18509 & 575 & 5580 & 15187 & 2747 \\
\hline
\end{tabular}

Table 7b: Impact of Quotas on Margins and Productivity

\begin{tabular}{||l|c|c|c|c|c||}
\hline \hline & $\begin{array}{c}\text { All } \\
\text { Firm- } \\
\text { Level }\end{array}$ & $\begin{array}{c}\text { Para- } \\
\text { Statals }\end{array}$ & $\begin{array}{c}\text { Private } \\
\text { High } \\
\text { Impact }\end{array}$ & $\begin{array}{c}\text { Private } \\
\text { Exports } \\
<25 \%\end{array}$ & $\begin{array}{c}\text { Private } \\
\text { Exports } \\
>25 \%\end{array}$ \\
\hline$B_{1}$ (Measure of Mark-ups) & $\begin{array}{c}1.089 \\
(.003)\end{array}$ & $\begin{array}{c}1.152 \\
(.019)\end{array}$ & $\begin{array}{c}1.042 \\
(.010)\end{array}$ & $\begin{array}{c}1.084 \\
(.003)\end{array}$ & $\begin{array}{c}1.061 \\
(0.011)\end{array}$ \\
\hline $\begin{array}{c}B_{3} \text { (Impact of Quotas on } \\
\text { Market Power) }\end{array}$ & $\begin{array}{c}.021 \\
(.006)\end{array}$ & $\begin{array}{c}.087 \\
(.040)\end{array}$ & $\begin{array}{c}0.071 \\
(.012)\end{array}$ & $\begin{array}{c}0.028 \\
(.006)\end{array}$ & $\begin{array}{c}0.028 \\
(0.014)\end{array}$ \\
\hline $\begin{array}{c}B_{5} \text { (Impact of Quotas on } \\
\text { Productivity) }\end{array}$ & -0.038 & -0.211 & -0.040 & $\begin{array}{c}-0.034 \\
(.012)\end{array}$ & $\begin{array}{c}-0.029 \\
(.027)\end{array}$ \\
\hline R-Square & .96 & .96 & .97 & .97 & .96 \\
\hline Number of Observations & 18508 & 615 & 5580 & 15186 & 2746 \\
\hline
\end{tabular}

Notes: Standard errors in parentheses. All equations include time dummies and firm fixed effects. 
Table 8: The Role of Capital Intensity in Adjustment to Trade Reform

\begin{tabular}{||l|l|l|l|l||}
\hline $\begin{array}{l}\text { Impact of Trade } \\
\text { Policy on: }\end{array}$ & \multicolumn{2}{|l||}{ Low Capital Labor/Ratio } & \multicolumn{2}{l||}{ High Capital/Labor Ratio } \\
\hline & Tariffs & Quotas & Tariffs & Quotas \\
\hline Employment & $\begin{array}{l}-0.048 \\
(.048)\end{array}$ & $\begin{array}{l}-0.040 \\
(.026)\end{array}$ & $\begin{array}{l}0.097 \\
(.060)\end{array}$ & $\begin{array}{l}0.110 \\
(.030)\end{array}$ \\
\hline Wages & $\begin{array}{l}0.054 \\
(.049)\end{array}$ & $\begin{array}{l}-0.026 \\
(.027)\end{array}$ & $\begin{array}{l}-0.065 \\
(.060)\end{array}$ & $\begin{array}{l}0.027 \\
(.030)\end{array}$ \\
\hline Mark-ups & $\begin{array}{l}0.000 \\
(.014)\end{array}$ & $\begin{array}{l}0.038 \\
(.009)\end{array}$ & $\begin{array}{l}0.015 \\
(.017)\end{array}$ & $\begin{array}{l}0.019 \\
(.009)\end{array}$ \\
\hline Productivity & $\begin{array}{l}0.014 \\
(.034)\end{array}$ & $\begin{array}{l}-0.014 \\
(.018)\end{array}$ & $\begin{array}{l}-0.110 \\
(.042)\end{array}$ & $\begin{array}{l}-0.057 \\
(.021)\end{array}$ \\
\hline
\end{tabular}

Notes: Standard errors in parentheses. The table shows coefficients on tariffs/quotas only. Underlying specifications are similar to those in Tables 4, 5, and 7 above. 
Table 9: The Evolution of Employment, K/L Ratios, Tariffs and Quotas by Sector.

\begin{tabular}{|c|c|c|c|c|c|c|c|c|}
\hline $\begin{array}{l}\mathrm{S} \\
\mathrm{E} \\
\mathrm{C} \\
\mathrm{T} \\
\mathrm{O} \\
\mathrm{R}\end{array}$ & $\begin{array}{l}1985 \\
\% \text { of } \\
\text { Emp. }\end{array}$ & $\begin{array}{c}1990 \% \\
\text { of } \\
\text { Emp. }\end{array}$ & $\begin{array}{l}\text { Labor } \\
\text { Force } \\
\text { growth } \\
85-90\end{array}$ & $\begin{array}{c}\mathrm{K} / \mathrm{L} \\
\text { Ratio in } \\
1985\end{array}$ & $\begin{array}{l}\text { Tar-iff } \\
\text { Rate } \\
\text { in } \\
1985\end{array}$ & $\begin{array}{l}\text { Quo- } \\
\text { tas in } \\
1985\end{array}$ & $\begin{array}{l}\text { Chnge } \\
\text { in Tar- } \\
\text { iffs } \\
85-90\end{array}$ & $\begin{array}{c}\text { Change } \\
\text { in } \\
\text { Quotas } \\
85-90\end{array}$ \\
\hline $\begin{array}{r}10 \\
11 \\
12 \\
13 \\
14 \\
15 \\
16 \\
17 \\
18 \\
19 \\
20 \\
21 \\
22 \\
23 \\
24 \\
25 \\
26 \\
27\end{array}$ & $\begin{array}{l}0.11 \\
0.13 \\
0.03 \\
0.21 \\
0.03 \\
0.03 \\
0.04 \\
0.05 \\
0.07 \\
0.01 \\
0.08 \\
0.02 \\
0.03 \\
0.04 \\
0.00 \\
0.08 \\
0.03 \\
0.00\end{array}$ & $\begin{array}{l}0.07 \\
0.14 \\
0.02 \\
0.17 \\
0.22 \\
0.02 \\
0.03 \\
0.04 \\
0.06 \\
0.00 \\
0.05 \\
0.02 \\
0.03 \\
0.03 \\
0.00 \\
0.07 \\
0.03 \\
0.00\end{array}$ & $\begin{array}{r}24.60 \\
64.38 \\
16.49 \\
34.64 \\
249.66 \\
27.02 \\
33.87 \\
29.65 \\
45.14 \\
-11.91 \\
13.09 \\
49.12 \\
53.74 \\
27.80 \\
98.07 \\
43.67 \\
42.55 \\
81.60\end{array}$ & $\begin{array}{r}152.65 \\
48.16 \\
153.88 \\
49.56 \\
7.00 \\
69.69 \\
23.87 \\
100.85 \\
186.01 \\
458.19 \\
28.69 \\
28.41 \\
60.50 \\
42.12 \\
53.19 \\
295.57 \\
56.33 \\
4.92\end{array}$ & $\begin{array}{l}0.47 \\
0.45 \\
0.88 \\
0.55 \\
0.74 \\
0.59 \\
0.29 \\
0.29 \\
0.22 \\
0.06 \\
0.29 \\
0.11 \\
0.18 \\
0.19 \\
0.18 \\
0.30 \\
0.48 \\
0.53\end{array}$ & $\begin{array}{l}0.49 \\
0.76 \\
0.99 \\
0.80 \\
0.96 \\
0.69 \\
0.81 \\
0.05 \\
0.24 \\
0.13 \\
0.30 \\
0.05 \\
0.37 \\
0.15 \\
0.02 \\
0.22 \\
0.13 \\
0.46\end{array}$ & $\begin{array}{r}-0.10 \\
-0.09 \\
-0.44 \\
-0.15 \\
-0.29 \\
-0.23 \\
-0.01 \\
0.05 \\
0.07 \\
0.04 \\
0.03 \\
0.07 \\
0.06 \\
0.07 \\
0.03 \\
-0.06 \\
-0.05 \\
-0.16\end{array}$ & $\begin{array}{c}-0.21 \\
-0.41 \\
-0.58 \\
-0.13 \\
-0.83 \\
-0.18 \\
-0.81 \\
-0.05 \\
-0.24 \\
-0.13 \\
-0.30 \\
-0.04 \\
-0.28 \\
-0.14 \\
-0.02 \\
-0.17 \\
-0.09 \\
-0.46\end{array}$ \\
\hline
\end{tabular}


1. This paper was prepared under funding from the research project, "Labor Markets in Developing Countries,", RPO 678-10. We would like to thank David Card, Simon Commander, Richard Freeman, Edward Leamer, Duncan Thomas, seminar participants at UCLA, UC Davis, the NBER, and the World Bank, and an anonymous referee for helpful comments.

1 In an earlier version of the paper, we also compared estimates of the effects of tariffs and quotas to those obtained using measures of import penetration. Arguably, the latter measures both the policies in effect, and the effect of those policies, whereas the former is a purer measure of policy. We found that the two types of measures were highly correlated and that the estimates obtained were very similar.

2. Nevertheless, Morocco is still far from an open economy. The tariff structure remains complicated despite the lowering of the maximum tariff and the dispersion of the tariff rates remains high, although significantly reduced in recent years. Morocco's tariff structure is such that tariffs rise with the stage of processing, resulting in effective rates of protection that are considerably higher than nominal rates. This effect is reinforced by the prevalence of quantitative restrictions (List B) on products at a high stage of processing.

3. The wage depends on the alternative wage, but is not expected to be exactly equal to the alternative wage: for example, in a contracting model, the own wage will be higher than the worker's next best alternative if there is any rent to be divided between workers and firms. Note that the worker's next best alternative wage will be some function of our ALTWAGE measure and the probability that a worker who lost his/her job would be re-employed in the same industry. Estimation of reduced form employment equations that omit the alternative wage produce very similar estimates of the effects of trade policy.

4. Similarly, the amount and type of capital at the start of the sample period will be captured by the fixed effect.

5. We first determined that most of these firms were not missing data because they were new entrants. 
6. There is no occupational breakdown available for temporary workers. In our analysis, we assume that temporary workers are mostly unskilled.

7. In principal, one could combine tariffs and quotas into a single index of protection.

However, there is no agreement in the trade literature about how this should be done.

Alternatively, one could estimate models (as we did in a previous version of this paper) that include tariffs, quotas, and the interaction between them. These models are considerably less transparent than those presented here, and do not yield additional insights into the effects of trade policy.

8. Arellano and Bond show that their procedure is more efficient than the usual solution of instrumenting lagged employment with second lags of the dependent variable.

9. For further details, see Arellano and Bond $(1988,1991)$.

10. See Chapter 7, Table 7.1.

11. It is possible that the largest reductions in tariffs and quotas were made in sectors where they were expected to have the smallest adverse impact (perhaps because those sectors were growing rapidly in any case). In this case, the estimated effects of tariffs and quotas will be biased towards zero. 